\title{
The Effect of Net Return on Investment Income in Jamkrida Jabar's Company
}

\author{
S. Sugiyanto \& M. Kustiawan \\ Universitas Pendidikan Indonesia \\ Bandung, Indonesia
}

\begin{abstract}
This research aimed to determine how much of the influence ROI (return on investment) to net income at PT Jamkrida Jabar. The research method used is descriptive method with quantitative approach. The technique used are the data collection observations, interviews, and literature study. The analysis technique used are the data normality test, correlation coefficient Pearson product-moment analysis, coefficient of determination, simple linear regression analysis, and hypothesis test using SPSS 20.0. With the result of Pearson product-moment correlation of 0.890 with significance level of 0.043 means very strong and positive influence, the value of determination coefficient of 0.793 roommates means the influence of $\mathrm{ROI}$ (return on investment) to net income of $79.3 \%$ while $217 \%$ influenced by other factors not examined. The problem were found from research conducted such as: the use of investment funds that are still not maximally that is deposit, the deposit interest in 2017 has decreased from the previous year, and the development of a relatively low of ROI (return on investment). The suggestions from the writer are: more investment in re-extension activity apart from deposits, the selections of deposit investment are done in futures, and more considering investment in real sector that are fixed assets.
\end{abstract}

Keywords-ROI; Net Income; Investment

\section{INTRODUCTION}

PT Jamkrida Jabar is one company which is a governmentowned of West Java, which provides solutions for cooperatives and SMEs (Small Medium Micro Enterprises) in problem credit guarantee institutions to access capital to banks and non-banks.

According to data produced by the author, during the period of 2012 to 2016 PT Jamkrida Jabar averages did not increase significant growth in the ROI (Return on Investment).

Improvement was achieved PT Jamkrida Jabar should be improved as it relates to the company's survival, particularly against profit. If the achievement of ROI experienced well growth, the profit generated will be in accordance with the target of achieving.

\section{LITERATURE REVIEW}

In order to be directed research and to facilitate the author in revealing discussion for the right target, it can be described the subject matter that is the effect of ROI to net profit at PT Jamkrida Jabar period of 2012-2016. The purpose of this study was to determine how much influence the ROI to net profit at PT Jamkrida Jabar period of 2012-2016 by conducting various studies that began with data collection, process, analyze and conclude the following purpose of the study is to determine:

- How big is the ROI for the period 2012-2016 at PT Jamkrida Jabar.

- $\quad$ Net profit growth during the period of 2012-2016 at PT Jamkrida Jabar.

- Effect of ROI on net income during the period from 2012 to 2016 in PT Jamkrid Jabar.

The understanding of ROI is one form of the profitability ratios which are intended to measure the ability of companies with total funds invested in assets that were used for the operation of the company to generate profits [1] Formula ROI in Kashmir (2008), namely:

$\mathrm{ROI}=\frac{\text { Earning After Interestand Tax }}{\text { Total Assets }} \times 100 \%$

Profit is the excess of revenues compared to the amount of the costs incurred [2].

\section{A). Research methods}

\section{METHOD}

Rresearch method is basically a scientific way to get data with a specific purpose and usefulness. The quantitative research is method research in the form of numbers and analysis using statistic [3]. Descriptive method is a method in researching a group of people, an object, a condition, a system of thought or a class of events in the present [4].

\section{B). Operational definition of variables}

Based on the title by author of "Influence the ROI on net income. Then it can be proposed variables to be studied in this research are:

- Independent variable is a variable that affects of the change dependent variable (variable bound). 
Independent variable in this study is the ROI in PT Jamkrida Jabar.

- Dependent variable (variable bound) is a variable that is affected or which become due, because of the independent variable. Dependent variable (variable bound) in this study is the net profit at PT Jamkrida Jabar.

\section{C). Population and sample}

According to Sugiyono (2008) states that "the population is generalization which consists of object/subject that has certain qualities and characteristics that establish by researchers to study and conclude". The population in this study is to take data from the financial statements of the balance sheet and income statement of PT Jamkrida Jabar.

According to Sugiyono (2008) "the sample is part of the number and characteristics of these populations". The sample in this study is the income statement and balance sheet of Jamkrida Jabar period 2012-2016.

\section{D) Data Collection Technique}

In this study, the authors used primary data and secondary data, primary data is the data that directly provide data to data collectors. Observation is obtained from data collection by direct observation of the object under study that the financial statements and interviews are data collection techniques by way of question and answer that is with PT Jamkrida Jabar accounting staff to conduct a preliminary study to find a problem that must be studied. And supporting secondary data from the primary data, obtained from the study of literature as a theoretical basis to discuss the problems being studied. I also use internet browsing because the data obtained from literature, books, and records related is still not sufficient to complete this study.

\section{E). Data Analysis Technique}

In this study, the data analysis technique used is inferential analysis is a statistical technique used to analyze the data sample and the results are enforced by random population".

The author tested this hypothesis using the analysis stage as follows:

\section{- Normality test data}

Normality test data in this study is used to determine whether the sample taken from the population distribution is normal or not. Good or decent data is data that has a normal distribution so that can use parametric statistics. If the data is not normal then parametric statistical techniques can not be used for statistical analysis tools but using parametric. Normality test data has done by using SPSS 20 software to facilitate data processing.

- Pearson product-moment correlation analysis Correlation analysis is used to find the relationship between the dependent variable and independent variable. Because the scale used in this analysis nominal shape, then used the formula Person product-moment.

- Analysis coefficient of determination
The coefficient of determination is used for determining the magnitude of the effect of independent variables on the dependent variable and measure how far the ability of the model to explain variations in the independent variable. The higher coefficient of determination then it will be better the ability of independent variables in explaining the dependent variable. $r^{2}$.

- Simple linear regression analysis

According to Sugiyono (2008), regression analysis is basically the analysis used to predict how much the value of the dependent variable, the value of the independent variable manipulated/permuted or raised and lowered. The regression analysis to study the relationship obtained and expressed in mathematical equations that express the functional relationship between variables.

- Hypothesis testing

Sugiyono (2008) argues that the statistical hypothesis is interpreted as a statement about the state of the population (parameters) to be verifiable based on data obtained from the sample of the research (statistical). When statistical values (data sample) obtained from the same data collection with a population parameter values or they are at intervals of a population parameter, then the hypothesis formulated $100 \%$ acceptable.

\section{RESULTS AND DISCUSSION}

\section{A). Conditions of ROI on PT Jamkrida Jabar period 2012 2016}

ROI condition in 2012 amounted to $(-2.10 \%)$, in 2013 by $(-0.10 \%)$ increased by $2 \%$ from 2012 , in 2014 amounted to $2.64 \%$ increased by $2.74 \%$ from 2014,2015 by $1.21 \%$ this year PT Jamkrida decreased about $1.37 \%$, in 2016 about $2.51 \%$ had increased by $1.3 \%$. Based on the data in PT Jamkrida Jabar can be seen that the growth rate of ROI obtained by PT Jamkrida Jabar is very volatile with significant fluctuations from year to year. ROI, the largest obtained by PT Jamkrida Jabar occurred in 2014, which amounted to $2.64 \%$, while the ROI, the lowest obtained by PT Jamkrida Jabar happened in 2012 is $-2.10 \%$ in 2012 PT Jamkrida Jabar suffered losses of IDR 557,243,519 and still few investments since 2012 is the beginning of the establishment of PT Jamkrida Jabar and this decline can be solved by an increase for next year. The averages percentage value of ROI overall each year is $0.83 \%$.

\section{B). Condition net profit at PT Jamkrida Jabar period 2012 - 2016}

Condition net profit at PT Jamkrida Jabar in 2012 amounted to (IDR 557,243,519), in 2013 amounted to (IDR $108,357,585)$ increased from the previous year of IDR $448,885,934$, in 2014 amounting to IDR 3,073,602,659 and increase of IDR 3,181,960,244 from 2013, 2015 amounting to IDR 2,148,315,172 this year decreased by (IDR 925,287,487), in 2016 amounting to IDR 5,388,679,660 This year is quite 
1) Simple linear regression analysis

Based on the results of simple linear regression analysis, the simple linear regression equation can be interpreted as follows:

$\mathrm{Y}=1,080,445,771.130+109,304,861,332.785 \mathrm{X}$

1. Regression coefficient of $109,304,861,332.785$ states that each increase of IDR 1 ROI will increase the profit of IDR $109,304,861,332.785$.

2. Constants IDR $1,080,445,771.130$ stated that the ROI is not considered $\mathrm{x}=0$, then the net profit $1,080,445,771.130$.

\section{CONCLUSION AND SUGGESTION}

because in 2012 was the first year of PT Jamkrida Jabar began its business activities. The average net income generated from year to year is IDR 9,994,996,387. In 2012 PT Jamkrida suffered losses of IDR 557,243,519.

\section{C). Influence ROI in net profit at PT Jamkrida Jabar Period $2012-2016$}

\section{- Normality test result data}

Based normality test results describing the results of the significance of these two variables, namely, an ROI of 0.987 and net income of 0.984 based on the criteria of testing the two variables is more than $0.05(0.987>0.05$ and $0.984>$ $0.05)$ so that can be concluded the two variables is accepted and normal distribution.

- Correlation coefficient analysis results in Pearson product-moment

Based on the analysis Pearson product-moment correlation coefficient can be concluded that the value of $\leq 0.05$ or $0.05 \leq$ $0.043 \mathrm{Sig}$, then Ho is rejected and accepted, which means significant. Thus a very strong relationship between the ROI and Net Income correlation value (r) of 0.890. Because the result of calculation of the correlation coefficient is in the interval from 0.80 to 1.00 (Sugiyono 2008), therefore it can be concluded that the degree of relationship between the ROI to net income in the category is very strong. $\mathrm{H}_{1}$.

- Determination coefficient analysis results

Based on the coefficient of determination obtained at 0.793 or $79.3 \%$. This means that the ROI amounted to $79.3 \%$ impact on net income while the remaining $21.7 \%$ influenced by IJP revenue (return on assurance services) and subrogation income. IJP revenue is PT Jamkrida Jabar revenues and Subrogation income is other income-other PT Jamkrida Jabar resulting from the payment of claims by secured previously been paid PT Jamkrida Jabar. This means that $21.7 \%$ Net Income affected by IJP Revenue and Revenue Subrogation. $r^{2}$.
Based on the results of research conducted at PT Jamkrida Jabar by taking the title on the Effect of ROI of the Net Profit at PT Jamkrida Jabar, the authors conclude as follows:

- $\quad$ ROI in PT Jamkrida Jabar during the period 2012 to 2016 is fluctuating decreased and increased from year to year. ROI, the highest occurred in 2014 amounting to $2.64 \%$. ROI, the lowest occurred in 2012 that is equal to $-2.10 \%$. If the average-the industry average of $5 \%$ means that the ROI PT Jamkrida Jabar still below average- the industry average. This is due to the low ratio of investment spiked in the financial sector, namely deposits.

- The net profit at PT Jamkrida Jabar during the period 2012-2016 has grown with the rise and decline fluctuate significantly from year to year. The net income that occurred in 2016 is IDR 5,388,679,660 an increase from the previous year by $2.937 \%$ increase in profit is the result of excellent. The net profit of the smallest occurred in 2012 and in 2012 PT Jamkrida suffered losses of IDR $557,243,519$.

- Based on the research note that the ROI strongly calculations using SPSS version 2.0. Moment Pearson correlation of 0.890 , with a determination coefficient of impact on net income while the remaining $21.7 \%$ influenced by other factors not examined by the author. In a hypothesis test conducted gets amounted to 3.389 t-test, this means that $\mathrm{t}>\mathrm{t}$ table $(3.389>3.182)$ so that there is a positive and significant influence between the ROI and net profit at PT Jamkrida Jabar.

After a study of the ROI in net profit at PT Jamkrida Jabar period of 2012-2016 the authors offer advice on research related to the following:

- For more investment activity expanded back to generate returns that can increase profits PT Jamkrida Jabar so that in the calculation of the ratio of ROI PT Jamkrida Jabar was above-average of this industry would be beneficial for investors in view of the company's performance. correlates to net income. This is shown by the results of 0.793 or $79.3 \%$, this means that indicates the ROI $79.3 \%$ 
- For a better selection of investment funds invested deposits in the bank deposit interest rate is quite high and carried forward.

- ROI is very influential in the fixed assets in the investment decision, you should be able to weigh PT Jamkrida Jabar to invest in the real sector of fixed assets for quite profitable and one of the ways the company to increase profits.

\section{REFERENCES}

[1] Munawir, M. 2014. Financial statement analysis. Yogyakarta: Liberty

[2] Kashmir, K. 2008. Financial statement analysis. Jakarta: PT Bajagrafindo Persada.

[3] Sugiyono, S. 2008. Quantitative research methods, qualitative and R\&D. Bandung: Alfabeta.

[4] Nazir, M. 2013). Research methods. Bogor: Ghalia Indonesia.

[5] Aliminsyah, P. 2006. Dictionary of terms finance and banking, Bandung: Rama Widya. 